\title{
Can zinc supplementation ameliorate cadmium-induced alterations in the bioelement content in rabbits?
}

\author{
Zorica Bulat ${ }^{1}$, Danijela Đukić-Ćosić ${ }^{1}$, Biljana Antonijević ${ }^{1}$, Aleksandra Buha ${ }^{1}$, Petar Bulat ${ }^{2,3}$, \\ Zoran Pavlović ${ }^{4}$, and Vesna Matović ${ }^{1}$
}

Department of Toxicology "Akademik Danilo Soldatovic", University of Belgrade - Faculty of Pharmacy ${ }^{l}$, Institute of Occupational Health ${ }^{2}$, University of Belgrade - Faculty of Medicine 3 , Belgrade, Institute for Public Health Požarevac, Požarevac ${ }^{4}$, Serbia

[Received in November 2016; Similarity Check in March 2017; Accepted in March 2017]

\begin{abstract}
The study was designed to investigate the influence of zinc ( $\mathrm{Zn}$ ) supplementation on cadmium-induced alterations in zinc, copper $(\mathrm{Cu})$, and magnesium $(\mathrm{Mg})$ status in rabbits. For this purpose, the concentrations of cadmium $(\mathrm{Cd}), \mathrm{Zn}, \mathrm{Cu}$, and $\mathrm{Mg}$ were estimated in the blood, liver, kidney, and bone. The rabbits were divided in a control group, a Cd group-animals intoxicated orally with $\mathrm{Cd}\left(10 \mathrm{mg} \mathrm{kg}^{-1} \mathrm{bw}\right.$, as aqueous solution of Cd-chloride), and a $\mathrm{Cd}+\mathrm{Zn}$ group-animals intoxicated with the same dose of $\mathrm{Cd}$ and co-treated with Zn (20 mg kg${ }^{-1} \mathrm{bw}$, as aqueous solution of Zn-sulphate). Solutions were administered orally, every day for 28 days. Sample mineralisation was performed with concentrated nitric acid $\left(\mathrm{HNO}_{3}\right)$ and perchloric acid $\left(\mathrm{HClO}_{4}\right)(4: 1)$ and metal concentrations were determined by atomic absorption spectrophotometry (AAS). Zinc supplementation improved some of Cd-induced disturbances in bioelement levels in the investigated tissues. Beneficial effects of $\mathrm{Zn}$ on $\mathrm{Zn}$ and $\mathrm{Cu}$ levels were observed in blood, as well as on the $\mathrm{Cu}$ kidney level. The calculated values for $\mathrm{Cu} / \mathrm{Zn}, \mathrm{Mg} / \mathrm{Zn}$, and $\mathrm{Mg} / \mathrm{Cu}$ ratios in blood suggest that $\mathrm{Zn}$ co-treatment reduces Cd-induced changes in bioelement ratios in blood.
\end{abstract}

KEY WORDS: biometals; biometal ratio; blood; bones; copper; kidney; liver; magnesium; interactions

Cadmium $(\mathrm{Cd})$ is a widely dispersed toxic metal of current occupational and environmental concern. It is responsible for numerous adverse effects, especially in the liver, lung, and testes following acute intoxication and in the kidney after chronic exposure. Recent data have confirmed the negative effects of low-level cadmium exposure on bone mineral density and calciotropic hormones (1). There are also examples of a significant association between $\mathrm{Cd}$ and myocardial infarction (2) as well as between $\mathrm{Cd}$ and prediabetes and diabetes mellitus in humans (3). Furthermore, cadmium acts as an inorganic xenoestrogen in humans: there is evidence that $\mathrm{Cd}$ possesses estrogenic activity $(4,5)$, while its thyroid-disrupting activities have been observed in experimental studies (6-8).

Over the past several decades, numerous experimental and epidemiological studies have demonstrated that $\mathrm{Cd}$ toxicity involves various cytotoxic and metabolic effects and multiple mechanisms, such as the induction of oxidative stress and apoptosis, aberrant gene expression, altered DNA structure, inhibition of ATP production in mitochondria, etc. (9-14). Furthermore, $\mathrm{Cd}$ toxic effects, especially as a result of chronic low-level exposure, can be connected with altered homeostasis of some bioelements $(15,16)$.

Correspondence to: Zorica Bulat, Department of Toxicology “Akademik Danilo Soldatović, Faculty of Pharmacy, University of Belgrade, Vojvode Stepe 450, 11221 Belgrade, Serbia, Phone: +381 11 3951252, Fax: +381 11 3972840, E-mail: zorica.bulat@pharmacy.bg.ac.rs
In 1970s, the TASK group on metal interactions (17) underlined the fact that toxic metals, $\mathrm{Cd}$ being one of them, can change the fate of biometals and vice versa, that some biometals can influence the absorption and distribution of $\mathrm{Cd}$. This was followed by many studies on $\mathrm{Cd}$ interactions with zinc $(\mathrm{Zn})$, copper $(\mathrm{Cu})$, iron $(\mathrm{Fe})$, calcium $(\mathrm{Ca})$, or magnesium $(\mathrm{Mg})$, which revealed that $\mathrm{Cd}$ intoxication influenced the homeostasis of biometals, causing predominantly their secondary deficit (15-19). Our previous investigation also confirmed disbalance of $\mathrm{Zn}, \mathrm{Cu}$, and $\mathrm{Mg}$ in rabbits exposed to prolonged $\mathrm{Cd}$ intoxication (20-22), as well as in mice and rats exposed to acute and subacute $\mathrm{Cd}$ intoxication (23-25). Furthermore, our results pointed to a significant decrease in $\mathrm{Zn}$ and $\mathrm{Mg}$ levels in blood and an increase in $\mathrm{Zn}$ content in the urine of nickel-cadmium battery workers (26).

On the other hand, there is growing evidence that supplementation with certain essential elements, especially $\mathrm{Zn}$, could have a protective role against $\mathrm{Cd}$ toxicity (27-31). The antagonism between $\mathrm{Cd}$ and $\mathrm{Zn}$ is well documented and is probably one of the most investigated toxic metalbioelement interactions (32,33). Thus, Rogalska et al. (29) concluded that $\mathrm{Zn}$ supplementation during chronic cadmium exposure may have a protective role against the proatherogenic action of $\mathrm{Cd}$ by preventing hyperlipidemia and lipid peroxidation in rats. The hepatoprotective $\mathrm{Zn}$ impact, observed in a prolonged $\mathrm{Cd}$ treatment of rats, was 
attributed to the antioxidative, antiapoptotic, and antiinflammatory properties of $\mathrm{Zn}$, as well as to its ability to stimulate regenerative processes and to reduce non-MTbound $\mathrm{Cd}$ levels in the liver $(30,34)$. A Zn co-treatment for four weeks succeeded in preventing $\mathrm{Cd}$ accumulation in the kidneys of rabbits (27), as well as Cd-MT induced proteinuria and calciuria in rats (35). A beneficial effect on the renal function was also observed in acute cadmium exposure in the investigation performed on the proximal tubules of rats. This was explained by $\mathrm{Zn}$ and $\mathrm{Cd}$ competition for transport proteins DMT1 and ZnT1 (28, 36). Furthermore, $\mathrm{Zn}$ supplementation lowered the risk of bone fractures, and increased bone density and biochemical bone properties in animals intoxicated with $\mathrm{Cd}$ for six months $(37,38)$. A beneficial, i.e. protective role of $\mathrm{Zn}$ against $\mathrm{Cd}$ toxicity is rather well documented and is prevalently explained by the ability of $\mathrm{Zn}$ to ameliorate Cd-induced oxidative stress, apoptosis, and necrosis (28, 29, 39).

Hu et al. (40) have even shown a protective effect of $\mathrm{Zn}$ against $\mathrm{Cd}$ carcinogenicity in rats, as they observed a decrease in proto-oncogene, c-jun and c-fos, expression and the increase in metallothionein (MT) genes' expression in prostate and p53 genes in testes. Additionally, Zn treatment of HeLa cells completely abolished the inhibition of Cdinduced DNA-protein interactions, which are essential for DNA repair (41). A recent investigation proved that $\mathrm{Zn}$ treatment boosted the immune function and the proliferation of lymphocytes in cadmium-treated rats (42).

Since our previous study confirmed the beneficial effect of $\mathrm{Zn}$ on $\mathrm{Cd}$ content in blood and organs of rabbits exposed to prolonged $\mathrm{Cd}$ intoxication (27), the aim of this study, performed under the same experimental conditions, was to find out whether $\mathrm{Zn}$ supplementation could counteract $\mathrm{Cd}$ induced disbalance of bioelements.

\section{MATERIALS AND METHODS}

\section{Chemicals}

All reagents and chemicals used were of analytical grade quality or higher purity. Cadmium chloride $\left(\mathrm{CdCl}_{2} \times \mathrm{H}_{2} \mathrm{O}\right)$ and zinc sulphate $\left(\mathrm{ZnSO}_{4} \times 7 \mathrm{H}_{2} \mathrm{O}\right)$, trace-pure concentrated nitric $\left(\mathrm{HNO}_{3}\right)$ and perchloric $\left(\mathrm{HClO}_{4}\right)$ acids, as well as metals standard solutions for atomic absorption spectrometry (AAS) were purchased from Merck (Darmstadt, Germany). Double-distilled water was used in the metal analysis.

\section{Animals and experimental protocol}

The experiment was performed on Oryctolagus cunniculus-Belgian hare rabbits, weighing 2.5-3.5 kg. Throughout the experiment, the animals were maintained in accordance with institutional and international guidelines (European Community Guidelines). The experimental protocol was approved by the Ethics Committee of the Military Medical Academy, Belgrade, Serbia.

Animals were kept under controlled conventional conditions (temperature $22 \pm 2{ }^{\circ} \mathrm{C}$, relative humidity of $50 \pm 10 \%, 12 \mathrm{~h}$ light-dark cycle) and were housed individually in standard cages. They had free access to drinking water and standard pellet diet (Complete mixture for young rabbits "Smeša K 16 \% proteina" The Veterinary Institute Subotica, Republic of Serbia) which contained min. $16 \%$ protein, max. $12 \%$ cellulose, min. $1.0 \% \mathrm{Ca}$, $\min .0 .8 \%$ P, min. $50 \mathrm{mg} \mathrm{kg}^{-1} \mathrm{Zn}$, and $\min .8 \mathrm{mg} \mathrm{kg}^{-1} \mathrm{Cu}$ (manufacturer's data). The following concentrations of metals were determined in our laboratory: $91 \mathrm{mg} \mathrm{kg}^{-1} \mathrm{Zn}$, $21 \mathrm{mg} \mathrm{kg}^{-1} \mathrm{Cu}, 2.4 \mathrm{~g} \mathrm{~kg}^{-1} \mathrm{Mg}$, and $19.2 \mu \mathrm{g} \mathrm{kg}^{-1} \mathrm{Cd}$ in diet and $148 \mu \mathrm{g} \mathrm{L}^{-1} \mathrm{Zn}, 10 \mu \mathrm{g} \mathrm{L}^{-1} \mathrm{Cu}, 15 \mathrm{mg} \mathrm{L}^{-1} \mathrm{Mg}$, while $\mathrm{Cd}$ concentration was under $0.1 \mu \mathrm{g} \mathrm{L}^{-1}$ in drinking water.

The rabbits were randomly divided into three groups, eight animals in each:

Control: non-treated animals.

Cd group: rabbits given a dose of $10 \mathrm{mg} \mathrm{kg}^{-1}$ body weight (bw) Cd orally, by orogastric tube, every day for four weeks, in the form of an aqueous solution of $\mathrm{CdCl}_{2}$ (the same $\mathrm{Cd}$ dose was applied in our previous investigation) (43).

$\mathrm{Cd}+\mathrm{Zn}$ group: rabbits exposed first to the same dose of $\mathrm{Cd}$ and then, one hour later, supplemented orally with $\mathrm{Zn}$, $20 \mathrm{mg} \mathrm{kg}^{-1}$ bw, as an aqueous solution of $\mathrm{ZnSO}_{4}$.

Before and during intoxication $\left(0,10^{\text {th }}, 14^{\text {th }}, 18^{\text {th }}, 22^{\text {nd }}\right.$, $25^{\text {th }}$, and $28^{\text {th }}$ day), blood samples were taken from the ear arteries using a cannula and collected in tubes with sodium heparin as anticoagulant.

At the end of the experiment ( $28^{\text {th }}$ day), all animals were sacrificed by injection of $3 \mathrm{~mL}$ of a $50 \mathrm{~g} \mathrm{~L}^{-1}$ sodium pentobarbitone solution in the marginal vein of the ear, followed by air embolism. The liver, kidney, and bone were excised and stored frozen $\left(-20{ }^{\circ} \mathrm{C}\right)$ until analysis.

\section{Sample preparation and analytical method}

Samples of whole blood and organs were mineralised with concentrated $\mathrm{HNO}_{3}$ and $\mathrm{HClO}_{4}$ in 4/1 ratio. After mineralisation and dilution with $0.1 \mathrm{~mol} \mathrm{~L}^{-1} \mathrm{HNO}_{3}$, metals were determined by flame atomic absorption spectrophotometry (FAAS, instrument GBC 932AA, Dandenong, Australia). The accuracy of the AAS analyses was validated with a reference sample from the National Bureau of Standards (NIST SRM 1577a bovine liver, National Institute of Standards and Technology, Gaithersburg, Maryland, USA).

\section{Statistical analyses}

Statistical analyses of results were conducted by oneway analysis of variance (ANOVA) followed by the LSD multiple comparison test for metal concentrations in blood and organs, as well as for Cd-bioelement ratios in blood. 
All values are presented as the means $\pm \mathrm{SD}$. The acceptable level of significance was set at $P<0.05$. All calculations were prepared with EXCEL 2007 and SPSS package PASW Statistics 18.

\section{RESULTS}

$\mathrm{Zn}, \mathrm{Cu}$, and $\mathrm{Mg}$ concentrations in blood and organs of rabbits exposed to $\mathrm{Cd}$ and co-treated with $\mathrm{Zn}$

As for $\mathrm{Zn}$, its level was reduced by about $30 \%$ at the end of the experiment in the $\mathrm{Cd}$ group, when compared to controls. However, in the $\mathrm{Cd}+\mathrm{Zn}$ group, $\mathrm{Zn}$ levels did not differ significantly from controls (Figure 1A). Although cadmium intoxication significantly elevated hepatic $\mathrm{Zn}$, the $\mathrm{Zn}$ liver content did not change in the $\mathrm{Cd}+\mathrm{Zn}$ group when compared with the Cd group. A similar pattern was observed in bones. In the kidney, no statistically significant changes of the $\mathrm{Zn}$ content were observed in either $\mathrm{Cd}$ or $\mathrm{Cd}+\mathrm{Zn}$ group if compared with controls (Table 1).

$\mathrm{Cu}$ blood levels in the $\mathrm{Cd}+\mathrm{Zn}$ group were significantly reduced if compared with $\mathrm{Cu}$ in the blood of $\mathrm{Cd}$ intoxicated animals, although these levels were still significantly higher than in controls (Figure 1B). Zn supplementation had a beneficial effect on the $\mathrm{Cu}$ content in the kidney: $\mathrm{Cu}$ levels significantly increased in the $\mathrm{Cd}$ group but did not change significantly in the $\mathrm{Cd}+\mathrm{Zn}$ group if compared with controls. No changes in the $\mathrm{Cu}$ content in the liver and bone were observed either between $\mathrm{Cd}$ and $\mathrm{Cd}+\mathrm{Zn}$ groups or between these groups and controls (Table 1).

$\mathrm{Zn}$ supplementation had no effect on the $\mathrm{Mg}$ level in blood, which reduced after $\mathrm{Cd}$ intoxication (Figure 1C). $\mathrm{Mg}$ concentration in the liver, kidney, and bone did not change significantly in both $\mathrm{Cd}$ and $\mathrm{Cd}+\mathrm{Zn}$ group if compared with controls.
The results on bioelement concentrations in the blood and organs of animals treated with $\mathrm{Cd}$ have already been published (43).

$\mathrm{Zn}, \mathrm{Cu}$, and $\mathrm{Mg}$ ratios in the blood of rabbits exposed to $\mathrm{Cd}$ or $\mathrm{Cd}+\mathrm{Zn}$

Bioelement ratios $\mathrm{Cu} / \mathrm{Zn}, \mathrm{Mg} / \mathrm{Zn}$, and $\mathrm{Mg} / \mathrm{Cu}$ were calculated for blood. Figure 2 presents the ratios of bioelements for the control, $\mathrm{Cd}$ (results previously presented in Ref. 43), and $\mathrm{Cd}+\mathrm{Zn}$ groups in blood. Zinc co-treatment counteracted the $\mathrm{Cd}$-induced increase in $\mathrm{Cu} / \mathrm{Zn}$ and $\mathrm{Mg} / \mathrm{Zn}$ ratios and the $\mathrm{Cd}$-induced decrease in $\mathrm{Mg} / \mathrm{Cu}$ ratio in blood.

\section{DISCUSSION}

The obtained results indicate that $\mathrm{Zn}$ supplementation improved the $\mathrm{Cd}$-induced changes in the $\mathrm{Zn}$ and $\mathrm{Cu}$ contents in certain rabbit tissues but had no beneficial effect on the $\mathrm{Mg}$ status in rabbits.

In blood, supplementation with $\mathrm{Zn}$ had a beneficial effect on the $\mathrm{Zn}$ content, which was reduced by about $30 \%$ in Cd-intoxicated animals if compared with controls. Cotreatment with $\mathrm{Zn}$ elevated blood $\mathrm{Zn}$ to control levels. This could be explained by the fact that $\mathrm{Cd}$ and $\mathrm{Zn}$ are absorbed from the gastrointestinal tract using the same divalent transport systems, such as divalent metal transporter-1 (DMT-1) and ZIP transporter family (18). Both metals compete for the same sites on these transporters and, consequently, the supplementation with $\mathrm{Zn}$ favours its absorption and increases its blood level. This finding is in accordance with the results of Brzóska et al. (37) who confirmed that $\mathrm{Zn}$ application in rats exposed to $5 \mathrm{mg} \mathrm{L}^{-1}$ $\mathrm{Cd}$ (by drinking water containing a concentration of either 30 or $60 \mathrm{mg} \mathrm{L}^{-1} \mathrm{Zn}$ for 12 months) resulted in $\mathrm{Zn}$ serum levels that did not differ from controls. However, the same

Table 1 The effect of $\mathrm{Zn}$ supplementation on $\mathrm{Zn}, \mathrm{Cu}$, and $\mathrm{Mg}$ concentrations in organs of rabbits after 28 days of Cd intoxication

\begin{tabular}{|c|c|c|c|}
\hline & Controls ${ }^{1)}$ & Cd group ${ }^{2)}$ & Cd+Zn group $^{3)}$ \\
\hline \multicolumn{4}{|c|}{$\mathrm{Zn}\left(\mu \mathrm{mol} \mathrm{kg}^{-1}\right)$} \\
\hline Liver & $640.73 \pm 112.27$ & $1037.02 \pm 128.61^{* *}$ & $1133.85 \pm 360.42^{* * *}$ \\
\hline Kidney & $677.15 \pm 106.09$ & $825.39 \pm 178.96$ & $755.49 \pm 155.56$ \\
\hline Bone $^{\text {a) }}$ & $3.75 \pm 0.42$ & $2.61 \pm 0.32^{*}$ & $2.72 \pm 0.42^{*}$ \\
\hline \multicolumn{4}{|c|}{$\mathrm{Cu}\left(\mu \mathrm{mol} \mathrm{kg}^{-1}\right)$} \\
\hline Liver & $52.11 \pm 9.64$ & $55.55 \pm 9.26$ & $46.32 \pm 9.23$ \\
\hline Kidney & $55.07 \pm 8.58$ & $74.88 \pm 11.37^{*}$ & $48.53 \pm 5.58^{\dagger \dagger}$ \\
\hline Bone & $199.65 \pm 34.67$ & $201.74 \pm 40.27$ & $200.46 \pm 32.35$ \\
\hline \multicolumn{4}{|c|}{$\mathrm{Mg}\left(\mathrm{mmol} \mathrm{kg}{ }^{-1}\right)$} \\
\hline Liver & $14.37 \pm 1.91$ & $14.94 \pm 1.94$ & $12.17 \pm 2.70^{\dagger}$ \\
\hline Kidney & $14.19 \pm 2.87$ & $14.99 \pm 3.12$ & $12.07 \pm 3.05^{\dagger}$ \\
\hline Bone & $343.46 \pm 22.31$ & $340.34 \pm 20.41$ & $333.29 \pm 31.46$ \\
\hline
\end{tabular}


A.

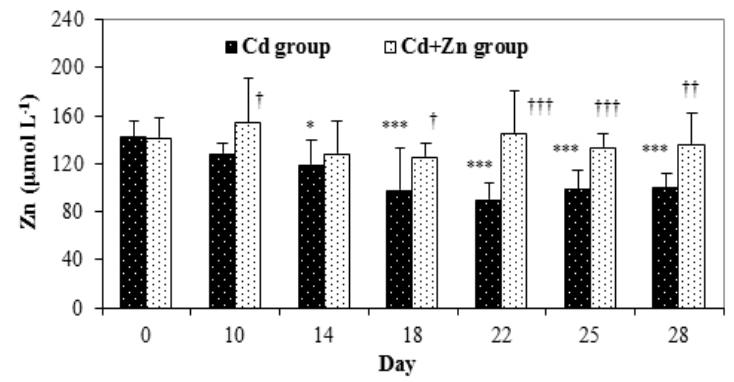

B.

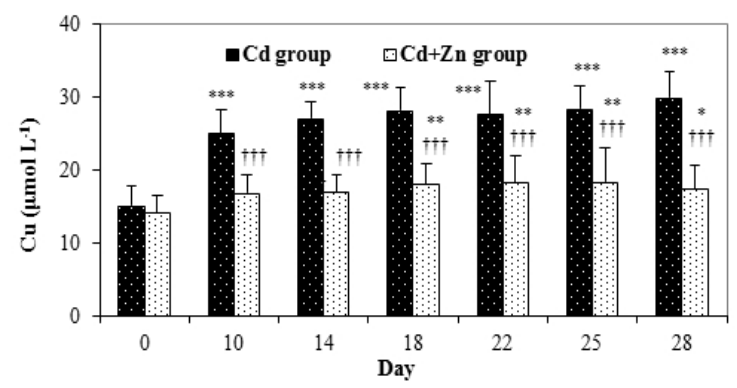

C.

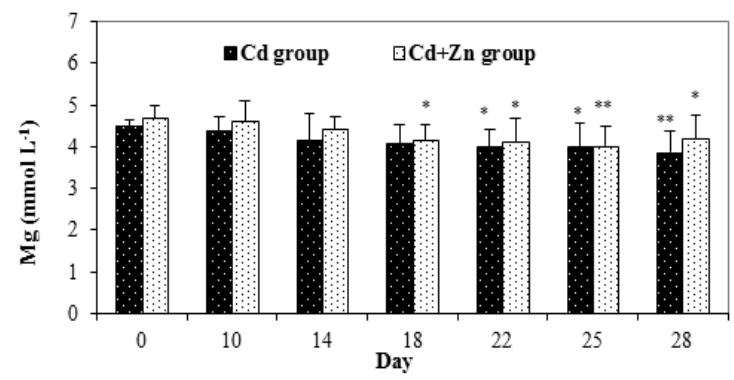

Figure $1 \mathrm{Zn}(A), C u(B)$, and $\mathrm{Mg}(C)$ concentrations in the blood of rabbits intoxicated with $C d$ and co-treated with Zn after 10, 14, 18, 22, 25, and 28 days; Cd group - intoxicated orally for four weeks with $C d\left(10 \mathrm{mg} \mathrm{kg}^{-1}\right.$ bw per day); $C d+Z n$ group - given $\mathrm{Zn}$ $\left(20 \mathrm{mg} \mathrm{kg}^{-1} \mathrm{bw}\right.$ ) one hour after Cd treatment. Marked values differ significantly (ANOVA + LSD test) from: * day 0 and $+C d$ group; $*,+P<0.05$ : **, $\uparrow P<0.01$; ***, $\uparrow+P<0.001$

authors did not prove the protective effect of $\mathrm{Zn}$ when a higher dose of Cd was used $\left(50 \mathrm{mg} \mathrm{L}^{-1}\right)$. A positive effect of $\mathrm{Zn}$ co-treatment has also been proven in an in vitro study (44) performed on Caco-2 TC71 cells - a model system for the investigation of intestinal epithelium. Moreover, literature data indicate that not only does $\mathrm{Zn}$ supplementation ameliorate the $\mathrm{Cd}$-induced disturbances of $\mathrm{Zn}$ levels, but it also influences and prevents $\mathrm{Cd}$ atherogenic effects through its effect on lipid metabolism whereby it prevents hyperlipidemia and hypercholesterolemia $(29,45)$.

A pronounced and rapid increase in blood $\mathrm{Cu}$ observed in Cd-intoxicated animals was not completely counteracted by $\mathrm{Zn}$ supplementation although $\mathrm{Zn}$ produced a significant decrease in blood $\mathrm{Cu}$ if compared with rats treated with $\mathrm{Cd}$ only. This phenomenon may be of concern since $\mathrm{Cu}$ is a Fenton metal that induces reactive oxidative species production and could be explained by $\mathrm{Zn}$ and $\mathrm{Cu}$ competition for the same metal transporters in cell membranes, as well as for MT in intestinal mucosa cells $(46,47)$.

Contrary to the effect on $\mathrm{Zn}$ and $\mathrm{Cu}$, co-treatment with $\mathrm{Zn}$ had no beneficial effect on the Mg blood content, which was significantly lowered in rabbits intoxicated with $\mathrm{Cd}$ only. It could be explained by $\mathrm{Mg}$ homeostasis, which is strictly controlled by intestinal absorption, its accumulation in bones, and elimination via urine. Furthermore, up-to-date literature data on metal transporters indicate that $\mathrm{Zn}$ and $\mathrm{Mg}$, in vivo, probably use different transport systems that are hardly mutually influenced. The protein ZIP family is involved in $\mathrm{Zn}$ transport, as well as in the transport of some other metals but unlikely in $\mathrm{Mg}$ transfer $(18,48)$. High affinity of TRPM7 transporters is proposed predominantly for $\mathrm{Mg}$ and $\mathrm{Ca}$, and to a lesser extent for $\mathrm{Zn}$ (49). Thus, the omitted beneficial effect of $\mathrm{Zn}$ could be more likely the consequence of forced $\mathrm{Mg}$ urine elimination induced by $\mathrm{Cd}$ (our unpublished data). However, in the study with rats simultaneously treated with $\mathrm{Cd}$ and $\mathrm{Zn}$, the plasma $\mathrm{Mg}$ levels and rate of urinary $\mathrm{Mg}$ elimination were in the range of controls indicating a beneficial effect of $\mathrm{Zn}$ (28). Similar results were obtained in sheep intoxicated with $\mathrm{Cd}$ and supplemented with $\mathrm{Zn}$ : $\mathrm{Zn}$ succeeded to restore normal $\mathrm{Mg}$ levels after their initial increase (50).

Cadmium intoxication had a strong influence on the $\mathrm{Zn}$ liver level resulting in two-times elevated $\mathrm{Zn}$ levels if compared with controls. Zn treatment was unable to sufficiently ameliorate this effect. Our results are in accordance with the study of Rogalska et al. (30) who also demonstrated zero effect of $\mathrm{Zn}$ supplementation on $\mathrm{Cd}$ induced enhancement of hepatic $\mathrm{Zn}$ level (six months of exposure to $50 \mathrm{mg} \mathrm{L}^{-1} \mathrm{Cd}$ and 30 or $60 \mathrm{mg} \mathrm{L}^{-1} \mathrm{Zn}$ in drinking water). These findings could be explained by the fact that $\mathrm{Zn}$ supplementation did not induce a decrease in the $\mathrm{Cd}$ content in rabbits intoxicated with $\mathrm{Cd}(27)$ although a strong influence of $\mathrm{Cd}$ on MT synthesis induction in the liver should also be taken into account. Furthermore, the protective effect of $\mathrm{Zn}$ against $\mathrm{Cd}$ toxicity could be also connected with some specific $\mathrm{Zn}$ mechanisms and properties that cannot be simply explained by $\mathrm{Zn}$ and $\mathrm{Cd}$ direct interactions. Thus, in a study of Jihen et al. (34), $500 \mathrm{mg} \mathrm{L}^{-1}$ of $\mathrm{Zn}$ supplementation in drinking water induced a strong protective $\mathrm{Zn}$ effect against $\mathrm{Cd}$ toxicity in rats treated with $200 \mathrm{mg} \mathrm{L}^{-1} \mathrm{Cd}$ for five weeks, although no influence on hepatic $\mathrm{Zn}$ level was observed.

It should be emphasised that the effect of excessive $\mathrm{Zn}$ intake on $\mathrm{Cu}$ kidney levels was similar to the $\mathrm{Zn}$ effect obtained in blood but was even more pronounced as the levels of $\mathrm{Cu}$ reached the control ones. This finding is of special importance having in mind that the kidney is the target organ of $\mathrm{Cd}$ toxicity and is in accordance with our previous investigation that pointed to a significant reduction of Cd levels caused by Zn co-treatment (27). Contrary to our results, administration of $\mathrm{Zn}$ concomitant with $\mathrm{Cd}$ in the form of Cd-MT did not change $\mathrm{Cu}$ concentration neither 
A

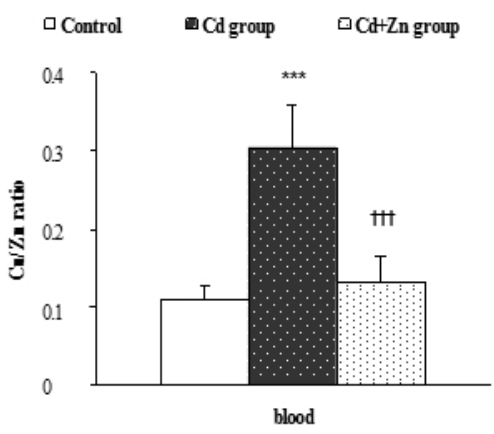

B.

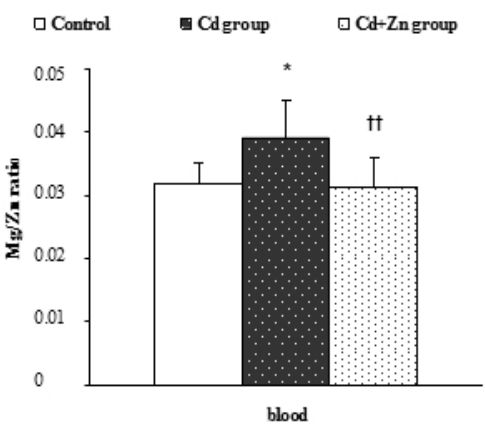

C.

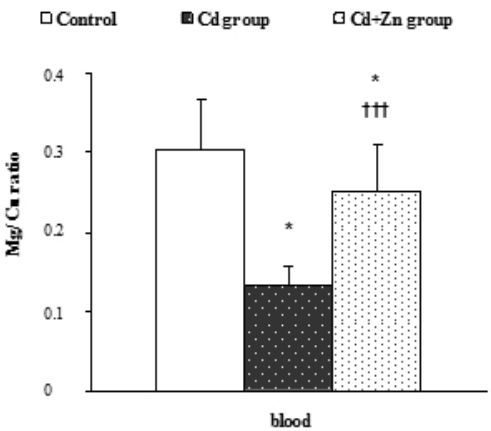

Figure 2 The effect of $C d$ exposure and $Z n$ supplementation on the $\mathrm{Cu} / \mathrm{Zn}$ ratio $(A), \mathrm{Mg} / \mathrm{Zn}$ ratio $(B)$, and $\mathrm{Mg} / \mathrm{Cu}$ ratio $(C)$ in the blood of rabbits after 28 days of treatment; Controls - non-treated animals; Cd group intoxicated orally for four weeks with $\mathrm{Cd}$ (10 mg kg-1 bw per day); Cd+Zn group given $\mathrm{Zn}\left(20 \mathrm{mg} \mathrm{kg}^{-1} \mathrm{bw}\right)$ one hour after $C d$ treatment. Marked values differ significantly $($ ANOVA + LSD test) from * control group and $+C d$ group; * $;$ $P<0.05$ : $P<<0.01$; ***, $\% P<0.001$

in the liver nor in the kidney of rats (35). The effect of $\mathrm{Zn}$ supplementation on $\mathrm{Cu}$ levels can be at least partly explained by the reduction of $\mathrm{Cd}$ body burden induced by $\mathrm{Zn}$ co-treatment. However, the observed $\mathrm{Zn}$ effect on $\mathrm{Cu}$ levels could be the consequence of interactions between these bioelements in the organism. Up-to-date knowledge on $\mathrm{Zn}$ and $\mathrm{Cu}$ interactions suggests their physiological antagonism, which is confirmed by the usage of $\mathrm{Zn}$ in the treatment of Wilson's disease $(46,47)$.

Osteotoxicity of $\mathrm{Cd}$ is well documented and could be at least partly explained by the interactions between $\mathrm{Cd}$ and bioelements in bones $(37,38)$. However, under our experimental conditions, the applied Cd dose of $10 \mathrm{mg} \mathrm{kg}^{-1}$ bw did not induce significant changes in the $\mathrm{Cu}$ and $\mathrm{Mg}$ content, although a significant decrease was achieved for $\mathrm{Zn}$ (43). No beneficial effect of $\mathrm{Zn}$ supplementation on the content of bioelements in bone was confirmed. Brzóska et al. (37) investigated the effect of $\mathrm{Zn}$ supplementation with two different doses (30 and $60 \mathrm{mg} \mathrm{L}^{-1}$ in drinking water) on the femur $\mathrm{Zn}$ concentration in rats exposed to 5 or $50 \mathrm{mg} \mathrm{L}^{-1} \mathrm{Cd}$ for 6 and 12 months. Both administered doses of $\mathrm{Zn}$ succeeded in preventing $\mathrm{Zn}$ deficit caused by low dose of $\mathrm{Cd}\left(5 \mathrm{mg} \mathrm{L}^{-1}\right)$. In rats exposed to a high dose of $\mathrm{Cd}$ (50 $\left.\mathrm{mg} \mathrm{L}^{-1}\right)$, the protection was observed only at a higher dose of $\mathrm{Zn}\left(60 \mathrm{mg} \mathrm{L}^{-1}\right)$ after six months. Our results and the results of Brzoska et al. (37) suggest that the interactions between $\mathrm{Cd}$ and $\mathrm{Zn}$ are dose-dependent. Furthermore, these investigations underline the duration of treatment as an important issue, indicating that the beneficial effect of $\mathrm{Zn}$ on its bone content in an organism exposed to $\mathrm{Cd}$ can be achieved only after prolonged $\mathrm{Zn}$ treatment.

With the goal to obtain more information on the effect of $\mathrm{Zn}$ supplementation on $\mathrm{Zn}, \mathrm{Cu}$, and $\mathrm{Mg}$ distribution pattern in the organism, the ratios of $\mathrm{Cu} / \mathrm{Zn}, \mathrm{Mg} / \mathrm{Cu}$, and $\mathrm{Mg} / \mathrm{Zn}$ in blood were calculated. Literature data, although rare, indicate that the ratios of bioelements provide a better insight into bioelement fate and their interactions in the organism under specific pathological conditions (51). Our results show that $\mathrm{Zn}$ had a beneficial effect on all investigated ratios in blood suggesting its positive effect on biometal distribution in blood. It should be emphasised that literature data underscore the $\mathrm{Cu} / \mathrm{Zn}$ ratio as a potential blood biomarker of different health disorders. Thus, increased values of the $\mathrm{Cu} / \mathrm{Zn}$ ratio were determined in developmental and behavioural disorders in children (52) and in some cases of cancer (53).

On the basis of our results, it can be concluded that $\mathrm{Zn}$ supplementation under the conditions of $\mathrm{Cd}$ exposure prevents the accumulation of $\mathrm{Cd}$ in the organism. Furthermore, it exerts beneficial effects, at least partly, on $\mathrm{Cd}$ induced disturbances in bioelements $\mathrm{Zn}$ and $\mathrm{Cu}$, with the most pronounced beneficial effect observed in blood.

\section{Acknowledgements}

This study was partly financially supported by the Ministry of Science and Technological Development (Grant No. III46009) and the University of Belgrade-Faculty of Pharmacy, Republic of Serbia.

Conflict of interest statement

The authors declare that there are no conflicts of interest.

\section{REFERENCES}

1. Bhattacharyya MH. Cadmium osteotoxicity in experimental animals: mechanisms and relationship to human exposures. Toxicol Appl Pharmacol 2009;238:258-65. doi: 10.1016/j. taap.2009.05.015 
2. Everett CJ, Frithsen IL. Association of urinary cadmium and myocardial infarction. Environ Res 2008;106:284-6. doi: 10.1016/j.envres.2007.10.009

3. Jacquet A, Ounnas F, Lénon M, Arnaud J, Demeilliers C, Moulis JM. Chronic exposure to low-level cadmium in diabetes: role of oxidative stress and comparison with polychlorinated biphenyls. Curr Drug Targets 2016;17:1385413. PMID: 26028051

4. Darbre PD. Metalloestrogens: an emerging class of inorganic xenoestrogens with potential to add to the oestrogenic burden of the human breast. J Appl Toxicol 2006;26:191-7. doi: $10.1002 /$ jat. 1135

5. Silva N, Peiris-John R, Wickremasinghe R, Senanayake H, Sathiakumar N. Cadmium a metalloestrogen: are we convinced? J Appl Toxicol 2012;32:318-32. doi: 10.1002/ jat.1771

6. Buha A, Antonijević B, Bulat Z, Jaćević V, Milovanović V, Matović $\mathrm{V}$. The impact of prolonged cadmium exposure and co-exposure with polychlorinated biphenyls on thyroid function in rats. Toxicol Lett 2013;221:83-90. doi: 10.1016/j. toxlet.2013.06.216

7. Ćurčić M, Janković S, Jaćević V, Stanković S, Vučinić S, Durgo K, Bulat Z, Antonijević B. Combined effects of cadmium and decabrominated diphenyl ether on thyroid hormones in rats. Arh Hig Rada Toksikol 2012;63:255-62. doi: 10.2478/10004-1254-63-2012-2179

8. Hammouda F, Messaoudi I, El Hani J, Baati T, Saïd K, Kerkeni A. Reversal of cadmium-induced thyroid dysfunction by selenium, zinc, or their combination in rat. Biol Trace Elem Res 2008;126:194-203. doi: 10.1007/s12011-0088194-8

9. Bertin G, Averbeck D. Cadmium: cellular effects, modifications of biomolecules, modulation of DNA repair and genotoxic consequences. Biochimie 2006;88:1549-59. doi: 10.1016/j.biochi.2006.10.001

10. Matović V, Buha A, Bulat Z, Đukić-Ćosić D. Cadmium toxicity revisited: focus on oxidative stress induction and interactions with zinc and magnesium. Arh Hig Rada Toksikol 2011;62:65-76. doi: 10.2478/10004-1254-62-2011-2075

11. Pulido MD, Parrish AR. Metal-induced apoptosis: mechanisms. Mutat Res 2003;533:227-41. doi: 10.1016/j. mrfmmm.2003.07.015

12. Waisberg M, Joseph P, Hale B, Beyersmann D. Molecular and cellular mechanisms of cadmium carcinogenesis Toxicology 2003;92:95-117. doi: 10.1016/S0300483X(03)00305-6

13. Matović, V, Buha A, Bulat Z, Đukić-Ćosić D, Miljković M, Ivanišević J, Kotur-Stevuljević J. Route-dependent effects of cadmium/cadmium and magnesium acute treatment on parameters of oxidative stress in rat liver. Food Chem Toxicol 2012;50:552-7. doi: 10.1016/j.fct.2011.12.035

14. Matović V, Buha A, Đukić-Ćosić D, Bulat Z. Insight into oxidative stress induced by lead and/or cadmium in blood, liver and kidneys. Food Chem Toxicol 2015;78:130-40. doi: 10.1016/j.fct.2015.02.011

15. Järup L, Berglund $M$, Elinder CG, Nordberg G, Vahter M. Health effects of cadmium exposure - a review of the literature and a risk estimate. Scand J Work Environ Health 1998;24(Suppl 1):1-51. PMID: 9569444

16. Peraza MA, Ayala-Fierro F, Barber DS, Casarez E, Rael LT Effects of micronutrients on metal toxicity. Environ Health Perspect 1998;106(Suppl 1):203-16. PMCID: PMC1533267
17. Task Group on Metal Interactions. Factors influencing metabolism and toxicity of metals: a consensus report. Environ Health Perspect 1978;25:3-42. PMCID: PMC1637186

18. Nordberg GF, Gerhardsson L, Broberg K, Mumtaz M, Ruiz P, Fowler BA. Interactions in metal toxicology. In: Nordberg GF, Fowler BA, Nordberg M, Friberg L, editors. Handbook on the toxicology of metals. $3^{\text {rd }}$ ed. Amsterdam: Elsevier; 2007. p. 446-86.

19. Moulis JM. Cellular mechanisms of cadmium toxicity related to the homeostasis of essential metals. Biometals 2010;23:87796. doi: 10.1007/s10534-010-9336-y

20. Matović V, Stojanović Z, Vujanović D, Soldatović D. Effects of prolonged cadmium intoxication on copper metabolism in rabbits. Arch Toxicol Kinet Xenobiot Metab 1997;5:41923.

21. Plamenac Z, Matović V, Vujanović D, Soldatović D. Zinc content in rabbits submitted to prolonged cadmium intoxication. In: Kovatsis AV, Tsoukali-Papadopoulou H, editors. Aspects on forensic toxicology. Thessaloniki: Tecnika Studio; 1995. p. 31-5.

22. Soldatović D, Matović V, Vujanović D, Stojanović Z. Contribution to interaction between magnesium and toxic metals: the effect of prolonged cadmium intoxication on magnesium metabolism in rabbits. Magnes Res 1998;11:2838. PMID: 9884986

23. Djukic-Ćosić D, Ninković M, Maličević Z, Plamenac-Bulat $Z$, Matović V. Effect of supplemental magnesium on the kidney levels of cadmium, zinc, and copper of mice exposed to toxic levels of cadmium. Biol Trace Elem Res 2006;114:281-91. doi: 10.1385/BTER:114:1:281

24. Djukić-Ćosić D, Ćurčić Jovanović M, Plamenac Bulat Z, Ninković M, Maličević Ž, Matović V. Relation between lipid peroxidation and iron concentration in mouse liver after acute and subacute cadmium intoxication. J Trace Elem Med Biol 2008;22:66-72. doi: 10.1016/j.jtemb.2007.09.024

25. Buha A, Bulat Z, Đukić-Ćosić D, Matović V. Effects of oral and intraperitoneal magnesium treatment against cadmiuminduced oxidative stress in plasma of rats. Arh Hig Rada Toksikol 2012;63:247-54. doi: 10.2478/10004-1254-632012-2217

26. Plamenac Bulat Z, Đukic-Ćosić D, Đokić M, Bulat P, Matović $\mathrm{V}$. Blood and urine cadmium and bioelements profile in nickel-cadmium battery workers in Serbia. Toxicol Ind Health 2009;25:129-35. doi: 10.1177/0748233709104488

27. Plamenac Bulat Z, Djukić-Ćosić D, Maličević Ž, Bulat P, Matović V. Zinc or magnesium supplementation modulates Cd intoxication in blood, kidney, spleen, and bone of rabbits. Biol Trace Elem Res 2008;124:110-7. doi: 10.1007/s12011008-8128-5

28. Jacquillet G, Barbier O, Cougnon M, Tauc M, Namorado MC, Martin D, Reyes JL, Poujeol P. Zinc protects renal function during cadmium intoxication in the rat. Am J Physiol Renal Physiol 2006;290:F127-37. doi: 10.1152/ ajprenal.00366.2004

29. Rogalska J, Brzóska MM, Roszczenko A, MoniuszkoJakoniuk J. Enhanced zinc consumption prevents cadmiuminduced alterations in lipid metabolism in male rats. Chem Biol Interact 2009; 177:142-52. doi: 10.1016/j.cbi.2008.09.011

30. Rogalska J, Pilat-Marcinkiewicz B, Brzóska MM. Protective effect of zinc against cadmium hepatotoxicity depends on this bioelement intake and level of cadmium exposure: A 
study in a rat model. Chem Biol Interact 2011;193:191-203. doi: 10.1016/j.cbi.2011.05.008

31. Lazarus M, Orct T, Jurasović J, Blanuša M. The effect of dietary selenium supplementation on cadmium absorption and retention in suckling rat. Biometals 2009;22:973-83. doi 10.1007/s10534-009-9249-9

32. Brzóska MM, Moniuszko-Jakoniuk J. Interactions between cadmium and zinc in the organism. Food Chem Toxicol 2001;39:967-80. doi: 10.1016/S0278-6915(01)00048-5

33. McCarty MF. Zinc and multi-mineral supplementation should mitigate the pathogenic impact of cadmium exposure. Med Hypotheses 2012;79:642-8. doi: 10.1016/j.mehy.2012.07.043

34. Jihen el H, Sonia S, Fatima H, Mohamed Tahar S, Abdelhamid $\mathrm{K}$. Interrelationships between cadmium, zinc and antioxidants in the liver of the rat exposed orally to relatively high doses of cadmium and zinc. Ecotoxicol Environ Saf 2011;74:2099 104. doi: 10.1016/j.ecoenv.2011.06.008

35. Liu X, Jin T, Nodberg GF, Sjöström M, Zhou Y. Influence of zinc and copper administration on metal disposition in rats with cadmium-metallothionein-induced nephrotoxicity. Toxicol Appl Pharmacol 1994;126:84-90. doi: 10.1006/ taap. 1994.1093

36. Barbier O, Dauby A, Jacquillet G, Tauc M, Poujeol P, Cougnon M. Zinc and cadmium interactions in a renal cell line derived from rabbit proximal tubule. Nephron Physiol 2005;99:74-84. doi: 10.1159/000083413

37. Brzóska MM, Rogalska J, Gałażyn-Sidorczuk M, Jurczuk M, Roszczenko A, Kulikowska-Karpińska E, MoniuszkoJakoniuk J. Effect of zinc supplementation on bone metabolism in male rats chronically exposed to cadmium. Toxicology 2007;237:89-103. doi: 10.1016/j.tox.2007.05.001

38. Brzóska MM, Galażyn-Sidorczuk M, Rogalska J, Roszczenko A, Jurczuk M, Majewska K, Moniuszko-Jakoniuk J. Beneficial effect of zinc supplementation on biomechanical properties of femoral distal end and femoral diaphysis of male rats chronically exposed to cadmium. Chem Biol Interact 2008;171:312-24. doi: 10.1016/j.cbi.2007.11.007

39. Jihen el H, Fatima H, Nouha A, Baati T, Imed M, Abdelhamid K. Cadmium retention increase: a probable key mechanism of the protective effect of zinc on cadmium-induced toxicity in the kidney. Toxicol Lett 2010;196:104-9. doi: 10.1016/j. toxlet.2010.04.006

40. Hu Y, Jin T, Zhou T, Pang B, Wang Y. Effects of zinc on gene expressions induced by cadmium in prostate and testes of rats. Biometals 2004;17:571-2. PMID: 15688867

41. Hartmann M, Hartwig A. Disturbance of DNA damage recognition after UV-irradiation by nickel(II) and cadmium(II) in mammalian cells. Carcinogenesis 1998;19:617-21. doi: 10.1093/carcin/19.4.617

42. Ebaid H, Hassan I, Bashandy S, Taha NA, Mahmood A, Alomar S, Alhazza I, Mashaly A, Rady A. Zinc improves the immune function and the proliferation of lymphocytes in cadmium-treated rats. Cent Eur J Immunol 2014;39:441-8. doi: 10.5114/ceji.2014.47726

43. Bulat Z, Đukić-Ćosić D, Antonijević B, Bulat P, Vujanović $\mathrm{D}$, Buha A, Matović V. Effect of magnesium supplementation on the distribution patterns of zinc, copper, and magnesium in rabbits exposed to prolonged cadmium intoxication. Sci World J 2012;Article ID 572514. doi:10.1100/2012/572514

44. Noël L, Huynh-Delerme C, Guérin T, Huet H, Frémy JM, Kolf-Clauw M. Cadmium accumulation and interactions with zinc, copper, and manganese, analysed by ICP-MS in a longterm Caco-2 TC7 cell model. Biometals 2006;19:473-81. doi: 10.1007/s10534-005-5147-y

45. Jemai H, Messaoudi I, Chaouch A, Kerkeni A. Protective effect of zinc supplementation on blood antioxidant defense system in rats exposed to cadmium. J Trace Elem Med Biol 2007;21:269-73. doi: 10.1016/j.jtemb.2007.08.001

46. Stefanidou M, Maravelias C, Dona A, Spiliopoulou C. Zinc: a multipurpose trace element. Arch Toxicol 2006;80:1-9. doi: 10.1007/s00204-005-0009-5

47. Stern BR, Solioz M, Krewski D, Aggett P, Aw T-C, Baker S, Crump K, Dourson M, Haber L, Hertzberg R, Keen C, Meek B, Rudenko L, Schoeny R, Slob W, Starr T. Copper and human health: biochemistry, genetics, and strategies for modeling dose-response relationships. J Toxicol Environ Health Part B Crit Rev 2007;10:157-222. doi: 10.1080/10937400600755911

48. Liuzzi JP, Cousins RJ. Mammalian zinc transporters. Annu Rev Nutr 2004;24:151-72. doi: 10.1146/annurev. nutr.24.012003.132402

49. Thévenod F. Catch me if you can! Novel aspects of cadmium transport in mammalian cells. Biometals 2010;23:857-75. doi: 10.1007/s10534-010-9309-1

50. Phillips CJC, Chiy PC, Omed HM. The effects of cadmium in feed, and its amelioration with zinc, on element balances in sheep. J Animal Sci 2004;82:2489-502. doi: $10.2527 / 2004.8282489 \mathrm{x}$

51. Nasiadek M, Krawczyk T, Sapota A. Tissue levels of cadmium and trace elements in patients with myoma and uterine cancer. Hum Exp Toxicol 2005;24:623-30. doi: 10.1191/0960327105ht575oa

52. Macedoni-Lukšič M, Gosar D, Bjřrklund G, Oražem J, Kodrič J, Lešnik-Musek P, Zupančič M, France-Štiglic A, Sešek-Briški A, Neubauer D, Osredkar J. Levels of metals in the blood and specific porphyrins in the urine in children with autism spectrum disorders. Biol Trace Elem Res 2015;163:2-10. doi: 10.1007/s12011-014-0121-6

53. Khoshdel Z, Naghibalhossaini F, Abdollahi K, Shojaei S, Moradi M, Malekzadeh M. Serum copper and zinc levels among Iranian colorectal cancer patients. Biol Trace Elem Res 2016;170:294-9. doi: 10.1007/s12011-014-0121-6 


\section{Može li utjecaj suplementacije cinkom poboljšati kadmijem izazvane promjene u razinama bioelemenata u} kunića?

Istraživanje je provedeno da bi se ispitao utjecaj suplementacije cinkom ( $\mathrm{Zn}$ ) na promjene u razinama cinka, bakra $(\mathrm{Cu})$ i magnezija (Mg) u kunića tretiranih kadmijem (Cd). U tu su svrhu koncentracije Cd, Zn, Cu i Mg određivane u krvi, jetri, bubregu i kostima. Kunići su bili podijeljeni u tri skupine: kontrolna skupina, Cd skupina - životinje koje su trovane kadmijem (10 mg kg-1 tjelesne mase, vodena otopina Cd-klorida) i u Cd+Zn skupinu - životinje koje su primale istu dozu kadmija i suplementaciju cinkom ( $20 \mathrm{mg} \mathrm{kg}^{-1}$ tjelesne mase, vodena otopina $\mathrm{Zn}$-sulfata). Otopine su davane 28 dana oralnim putem. Uzorci su mineralizirani koncentriranom dušičnom kiselinom $\left(\mathrm{HNO}_{3}\right)$ i perklornom kiselinom $\left(\mathrm{HClO}_{4}\right)$ (4:1), a koncentracija metala određena je primjenom atomske apsorpcijske spektrofotometrije (AAS). Suplementacija cinkom uspjela je ublažiti poremećaj u razini bioelemenata, do kojega je dovela izloženost kadmiju u ispitivanim organima. Primjena cinka imala je povoljan učinak na razinu Zn i Cu u krvi i bubregu. Analiza odnosa bioelemenata u krvi, izražena kao $\mathrm{Cu} / \mathrm{Zn}, \mathrm{Mg} / \mathrm{Zn}$ i $\mathrm{Mg} / \mathrm{Cu}$, upućuje na to da primjena cinka može u značajnoj mjeri smanjiti promjene u odnosima ispitivanih bioelemenata do kojih dovodi izloženost kadmiju.

KLJUČNE RIJEČI: bakar; biometali; bubreg; interakcije; jetra; kosti; krv; magnezij; omjer biometala 